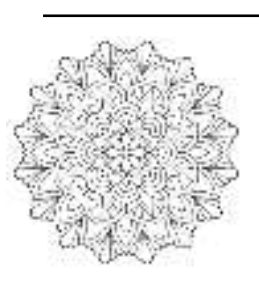

AL HIKMAH: INDONESIAN JOURNAL OF EARLY CHILDHOOD ISLAMIC EDUCATION

ISSN (P): 2550-2200, ISSN (E): 2550-1100, VOL. 4 (1), 2020, PP. $1-9$

http://journal.iaialhikmahtuban.ac.id/index.php/ijecie

\title{
PENGARUH KONSEP DIRI, MASA KERJA DAN LATAR BELAKANG PENDIDIKAN TERHADAP MOTIVASI KERJA KEPALA $R A$
}

\author{
Ida Windi Wahyuni ${ }^{1}$, Alucyana ${ }^{2}$, Dian Tri Utami ${ }^{3}$ \\ ${ }^{1,2,3}$ Pendidikan Islam Anak Usia Dini, Fakultas Agama Islam, Universitas Islam Riau \\ idawindi@fis.uir.ac.id \\ Abstrak
}

\begin{abstract}
Penelitian ini fokus pada konsep diri, masa kerja, dan latar belakang pendidikan yang berpengaruh terhadap motivasi kerja kepala RA Kota Pekanbaru. Hipotesis yang diajukan adalah ada pengaruh antara konsep diri, masa kerja dan latar belakang pendidikan terhadap motivasi kerja Kepala Raudhatul Athfal Kota Pekanbaru. Subyek penelitian ini 27 Kepala RA Kota Pekanbaru. Teknik analisis datanya adalah analisis korelasi dalam program SPSS for windows. Hasil penelitian antara konsep diri, masa kerja dan latar belakang pendidikan memiliki pengaruh terhadap motivasi kerja kepala RA, dinyatakan dalam hasil penelitian dengan nilai Rsquare sebesar $28 \%(0,282)$, lebih tinggi dari nilai $\sigma=5 \%$ dan nilai $\mathrm{F}$ sebesar 6,913 di atas nilai $10 \%$ yang menunjukkan tidak adanya gejala multikolinearitas. Penelitian ini menyatakan bahwa konsep diri, masa kerja dan latar belakang pendidikan berpengaruh cukup tinggi terhadap motivasi kerja kepala RA Kota Pekanbaru. Pengaruh konsep diri, masa kerja dan latar belakang pendidikan terhadap motivasi kerja menunjukkan nilai signikansi (Sig.) 0,010 dengan nilai $\sigma$ (derajat signifikan) 0,05 , artinya $0,01<$ 0,05 ; maknanaya adalah terdapat pengaruh yang signifikan antara pengaruh konsep diri, masa kerja dan latar belakang pendidikan terhadap motivasi kerja kepala RA Kota Pekanbaru..
\end{abstract}

Kata Kunci: Motivasi Kerja, Konsep Diri, Pendidikan, Kepala RA

\section{Abstract}

This study focuses on self-concept, years of service, and educational background that affect the work motivation of the head of RA Pekanbaru City. The hypothesis proposed is that there is an influence between self-concept, years of service and educational background on the work motivation of the Head of The Raudhatul Athfal City of Pekanbaru. The subjects of this study were 27 RA Heads of Pekanbaru City. The data analysis technique is correlation analysis in the SPSS for windows program. The results of the study between self-concept, years of service and educational background have an influence on the work motivation of RA heads, expressed in the results of the study with a R Square value of $28 \%(0.282)$, higher than the value of $\sigma=5 \%$ and an F value of 6.913 above the value $10 \%$ showing no symptoms of multicollinearity. This study states that self-concept, years of service and educational background have a significant effect on the work motivation of the head of the RA City of Pekanbaru. The effect of self-concept, years of service and educational background on work motivation shows a significance value (Sig.) Of 0.010 with a value of $\sigma$ (significant degree) 0.05 , meaning $0.01<0.05$; meaning is that there is a significant influence between the influence of self-concept, years of service and educational background on the work motivation of RA Kota Pekanbaru head. .

Keywords: Work Motivation, SelfConcept, Education, Head RA 


\section{PENDAHULUAN}

Pengembangan kemampuan dan pembentukan watak serta keberadapan bangsa bermartabatuntuk mencerdaskan kehidupan bangsa termaktub dalam Undang-undang Nomor 20 Tahun 2003. Adapun tujuannya adalah agar potensi siswa dapat mengalami perkembangan yang baik sehingga terwujud insan yang memiliki iman dan taqwa kepada Tuhan Yang Maha Esa (Mulyasa, 2012).

Sekolah sebagai lembaga pendidikan dikelola oleh organisasi sekolah itu sendiri sebagaimana diatur dalam manajemen berbasis sekolah untuk meningkatkan kualitas lingkungan kerja (ismail, 2018). Kewenangan inilah memberikan peluang kepada pihak sekolah untuk otonomi, tanggungjawab dan berpartisipasi dalam melaksanakan programprogram sekolah (Nurkholis, 2005). Sekolah yang berkualitas adalah sekolah yang memiliki beberapa komponen pendukung sebagai pedoman utama kemajuan sekolah tersebut. Komponen pendukung yang dimaksud, yakni kepala sekolah, guru, siswa, keterlibatan orang tua pada program sekolah dan manajemen sekolah.

Tanggung jawab seorang kepala sekolah untuk keberlangsungan sekolahnya, komitmen tinggi dalam menjalankan tugasnya (Iskandar, 2013) dan dituntut memiliki profesionalisme yang maksimal (Librianty, 2019) merupakan tugas kepala sekolah. Seorang kepala sekolah akan menyumbangkan seluruh kemampuan, pikiran, kinerja, dan inovasinya untuk mewujudkan tujuan pendidikan. Kepala sekolah dengan motivasi tinggi dapat meraih hasil yang optimal dalam kepemimpinannya, namun jika memiliki motivasi rendah akan terbentur oleh beberapa masalah dan menghindari pekerjaan yang butuh kinerja yang tinggi.

Sebagaimana yang diuraikan oleh Winardi (dalam Rahmania, dkk, 2014) menjelaskan bahwa motivasi merupakan suatu kekuatan potensial yang dimiliki oleh seseorang dapat dikembangkan sendiri atau sekelompok orang yang berpengaruh terhadap hasil kinerjanya. Motivasi menjadi penggerak seseorang untuk mengukir prestasi (Rivai dan Arifin, 2013). Sebagaimana dalam QS Az-Zumar (39) Ayat 9 menjelaskan bahwa orang-orang diberikan kemampuan oleh Allah SWT merupakan orang yang dapat menerima pelajaran (Munfarijah, 2015). Faktor-faktor yang mempengaruhi motivasi kerja kepala sekolah, antara lain, kebutuhan akan prestasi, afiliasi, kekuasaan (Mc. Chelland dalam Hasibuan, 2017), konsep diri, latar belakang pendidikan, masa kerja, kepemimpinan, kinerja, dan budaya organisasi.

Motivasi kerja adalah dorongan yang timbul dari diri sendiri baik yang berasal dari dalam atau dari luar dalam melakukan suatu pekerjaan dengan semangat tinggi, menggunakan kemampuan dan ketrampilan yang dimilikinya untuk mencapai tujuan tertentu (Schunk, 2012). Siagian (dalam Mashiitahili, 2010). Motivasi kerja timbul karena adanya 
Ida Windi Wahyuni, Alucyana, Dian Tri Utami (Pengaruh Konsep Diri, Masa Kerja)

kebutuhan. Kebutuhan yang telah terpenuhi akan menjadi kepuasan tersendiri dan mempengaruhi perilaku seseorang.

Konsep diri merupakan pandangan atau keyakinan diri terhadap keseluruhan diri, baik yang menyangkut kelebihan maupun kekurangan diri, sehingga mempunyai pengaruh yang besar terhadap keseluruhan perilaku yang ditampilkan (Wahyuni, 2011). Konsep diri adalah hasil dari proses belajar yang berkembang dari hasil interkasi dengan lingkungan dan bukan dari 3able3 keturunan. Konsep diri digambarkan sebagai penilaian pada dirinya sendiri secara pribadi. Konsep diri yang baik berarti dapat memahami dirinya sendiri dan mudah untuk introspeksi diri. Aspek-aspek konsep diri menurut Berzonsky (1981 dalam Maria Ulfah, 2007) adalah aspek fisik, sosial, moral dan psikis. Kepribadian, percaya diri, bertanggung jawab, pengalaman, kemandirian, kedewasaan, perasaan dan kesadaran.

Selanjutnya, peran masa kerja juga berpengaruh terhadap motivasi kerja kepala sekolah. Semakin lama masa kerjanya berpengaruh terhadap motivasi kerja, kinerja dan kepemimpinan seseorang. Masa kerja adalah seberapa lama seseorang bekerja di suatu lembaga dimana dipengaruhi juga oleh unsur pengalaman dan proses belajar sebagai dirinya sendiri, diri dengan lingkungannya, manajemen lembaga dan kepemimpinan yang dialami selama bekerja.

Pengelolaan sekolah yang baik jika berhasil dicapai oleh kepala sekolah sebagai pimpinan menjadi kebanggaan bagi komponen yang berada dalam lingkungan sekolah itu sendiri. Kepala sekolah dengan latar belakang sarjana (S1) bidang pendidikan akan mudah penyeuaian dirinya pada lingkungan sekolah. Permasalahan-permasalahan yang muncul di sekolah menjadi tantangan dalam keberhasilan suatu kepemimpinan. Namun terkadang, jabatan kepala sekolah yang diembannya karena sekolah atau yayasannya milik sendiri.

Berdasarkan data yang diperoleh dari Kelompok Kerja Kepala Raudhatul Athfal (RA) Provinsi Riau dinyatakan bahwa latar belakang Kepala RA memiliki latar belakang Pendidikan yang beragam, hanya sebagian kecil (sekitar 30\%) yang berlatar belakang Pendidikan sarjana (S1) Pendidikan Anak Usia Dini. Sebagian besar kepala RA yang memiliki latar belakang sarjana umum non pendidikan, seperti jurusan 3able, ekonomi, teknik, pertanian, ataupun sains. Latar belakang pendidikan kepala RA berpengaruh terhadap kepimpinanannya. Selain itu, kurikulum RA menuntut kegiatan belajar mengajar secara umum yang diintegrasikan dalam agama Islam.

Raudhatul Athfal (RA) merupakan tahapan pendidikan formal pada anak yang berusia 4-6 tahun yang dikelola langsung oleh Kementrian Agama. RA sederajat dengan TK/PAUD, 
Ida Windi Wahyuni, Alucyana, Dian Tri Utami (Pengaruh Konsep Diri, Masa Kerja)

dimana kegiatan belajar mengajar focus pada pertumbuhan serta perkembangan psikis dan fisik anak untuk mempersiapkan diri ke tahapan sekolah dasar. Tujuan didirikan RA ialah membimbing dan mendidik anak untuk meningkatkan pengetahuan, pengalaman, kemampuan penyesuaian diri dengan lingkungan yang baru di luar keluarganya sehingga aspek perkembangannya lebih sempurna.

Berdasarkan uraian tersebut di atas yang menjadi latar belakang permasalahan penelitian ini disusun. Peneliti tertarik untuk mengetahui apakah ada pengaruhnya konsep diri, masa kerja dan latar belakang pendidikan terhadap motivasi kerja Kepala Raudhatul Athfal Kota Pekanbaru. Adapun hipotesis yang diajukan adalah ada pengaruh antara konsep diri, masa kerja dan latar belakang pendidikan terhadap motivasi kerja Kepala Raudhatul Athfal Kota Pekanbaru.

\section{METODE}

Penelitian ini melibatkan variabel konsep diri, masa kerja dan latar belakang pendidikan sebagai variable bebas, sedangkan motivasi kerja merupakan variabel tergantung. Kepala RA Kota Pekanbaru yang berjumlah 27 orang menjadi responden penelitian, dimana pengumpulan datanya dilakukan saat pelatihan kepemimpinan bagi kepala RA.

Alat ukur yang digunakan dalam penelitian ini adalah skala motivasi kerja dan skala konsep diri. Penelitian menggunakan variabel motivasi kerja kepala sekolah yang diangkat dari buku Pay and Organization Development dalam B. Siswanto Sastrohadiwiryo (2005) yang telah diadaptasi dari hasil penelitian Prasesti Puspita Dewi Kunadi (2012) dengan hasil uji reliabilitas alpha cronbach sebesar 0.923 dengan aspek kinerja, kesempatan dan penghargaan. Instrumen konsep diri menggunakan instrument yang telah diadaptasi dari Teknik "The Q-Sort" yang dikembangkan oleh Stephen Son (1952). Teknik "The Q-Sort" merupakan instrumen untuk mendapatkan gambaran berbagai aspek dari diri. Peneliti menggunakan instrumen yang telah digunakan oleh Sri Rosilawati (2005) yang mencakup kepribadian, percaya diri, bertanggung jawab, pengalaman, kemandirian, kedewasaan, perasaan dan kesadaran. Untuk menguji hipotesis yang telah diajukan, peneliti menganalisisnya dengan analisa korelasi teknik regresi pada program SPSS.

\section{HASIL DAN PEMBAHASAN}

Hasil uji motivasi kerja dengan analisa deskripsi diperoleh nilai minimal sebesar 70 hingga 93 sebagai nilai maksimal, mean (rerata) 80,67, standar deviasi 6,78, median (nilai 
Ida Windi Wahyuni, Alucyana, Dian Tri Utami (Pengaruh Konsep Diri, Masa Kerja) tengah) 78,0, dan modus (kecenderungan muncul) 77,0. Deskripsi data motivasi kerja kepala RA di Kota Pekanbaru dijelaskan pada tabel berikut.

Tabel 1. Deskripsi Motivasi Kerja

\begin{tabular}{|l|l|l|c|c|}
\hline \multicolumn{2}{|c|}{ Skor } & Kategorisasi & Jumlah Subyek & Prosentase \\
\hline$(\mu+1,0 \partial) \leq X$ & $72 \leq X$ & Tinggi & 26 & 96,3 \\
\hline$(\mu-1,0 \partial) \leq X<(\mu+1,0 \partial)$ & $60 \leq X<72$ & Sedang & 1 & 3,7 \\
\hline$X<(\mu-1,0 \partial)$ & $X<60$ & rendah & 0 & 0 \\
\hline
\end{tabular}

Tabel tersebut menyatakan bahwa Kepala RA Kota Pekanbaru yang memiliki kategori tinggi sebanyak 26 orang $(96,3 \%), 1$ orang $(3,7 \%)$ termasuk dalam kategori sedang, dan tidak ada responden yang memiliki kategori rendah. Selanjutnya, disimpulkan bahwa Kepala RA Kota Pekanbaru memiliki motivasi kerja yang tinggi.

Hasil uji deskriptif untuk variabel konsep diri diperoleh skor minimal sebesar 69 dengan nilai maksimal 90, mean (rerata) 80, standar deviasi 5,72, median (nilai tengah) 79, dan modus (kecenderungan muncul) 78. Deskripsi data konsep diri kepala RA di Kota Pekanbaru dijelaskan pada tabel berikut.

Tabel 2. Deskripsi Konsep Diri

\begin{tabular}{|l|l|l|c|c|}
\hline \multicolumn{2}{|c|}{ Skor } & Kategorisasi & Jumlah Subyek & Prosentase \\
\hline$(\mu+1,0 \partial) \leq X$ & $75 \leq X$ & Tinggi & 27 & 100 \\
\hline$(\mu-1,0 \partial) \leq X<(\mu+1,0 \partial)$ & $62,5 \leq X<75$ & Sedang & 0 & 0 \\
\hline$X<(\mu-1,0 \partial)$ & $X<62,5$ & Rendah & 0 & 0 \\
\hline
\end{tabular}

Tabel tersebut menyatakan bahwa Kepala RA Kota Pekanbaru yang memiliki konsep diri kategori tinggi ada 7 orang $(100 \%)$ dan tidak ada satu pun subyek penelitian termasuk pada kategori sedang ataupun rendah. Sehingga dapat disimpulkan Kepala RA Kota Pekanbaru memiliki konsep diri yang tinggi.

Tabel 3. Deskripsi Masa Kerja

\begin{tabular}{|l|c|l|}
\hline \multicolumn{1}{|c|}{ Masa Kerja } & Jumlah Subyek & Prosentase \\
\hline $0-3$ tahun & 5 & 18,5 \\
\hline $4-6$ tahun & 5 & 18,5 \\
\hline $7-9$ tahun & 9 & 33,3 \\
\hline $10-12$ tahun & 5 & 18,5 \\
\hline $13-15$ tahun & 3 & 11,1 \\
\hline
\end{tabular}

Tabel tersebut menjelaskan bahwa masa kerja antara 7 sampai 9 tahun berjumlah 9 orang (33,3\%), merupakan jumlah yang paling bamyak diantara masa kerja yang lain. Masa kerja yang paling sedikit antara 13 - 15 tahun, yaitu berjumlah 3 orang $(11,1 \%)$. Mean masa kerja adalah 2,85 dengan nilai standar deviasi sebesar 1,2623. 
Tabel 4. Deskripsi Latar Belakang Pendidikan

\begin{tabular}{|l|c|c|}
\hline Latar Belakang Pendidikan & Jumlah Subyek & Prosentase \\
\hline S1 Agama & 12 & 44 \\
\hline S1 Pendidikan & 10 & 37 \\
\hline S1 Umum & 5 & 19 \\
\hline
\end{tabular}

Tabel tersebut menjelaskan bahwa latar belakang pendidikan sarjana agama berjumlah 12 orang (44\%), merupakan jumlah yang paling bamyak diantara masa kerja yang lain. Latar belakang pendiidkan dengan sarjana umum (Sarjana Ekonomi, Sarjana Hukum, Sarjana Teknik) yang paling sedikit yaitu berjumlah 5 orang (19\%). Mean latar belakang pendidikan adalah 1,81 dengan nilai standar deviasi sebesar 0,736.

Hasil analisa statistik pada konsep diri dengan motivasi kerja Kepala RA menunjukkan nilai koefisien korelasi (r) sebesar 0,279 dan koefisien determinasi $\left(\mathrm{r}^{2}\right)$ sebesar 0,078. Artinya konsep diri memiliki pengaruh yang signifikan terhadap motivasi kerja. Walaupun berpengaruh hanya $1 \%$ namun dapat dikatakan bahwa motivasi kerja dapat dipengaruhi oleh konsep diri. Motivasi kerja dan konsep diri para kepala RA Kota Pekanbaru menunjukkan hasil dengan kategori yang tinggi. Dengan hasil yang didapatkan membuktikan hipotesis yang diajukan bahwa konsep diri makin tinggi pada kepala RA, maka motivasi kerjanya juga makin tinggi.

Konsep diri positif yang dimiliki oleh seseorang dapat berperan penting untuk memahami diri sebagai individu yang berkepribadian yang baik sehingga penilaian pada dirinya akan semakin baik pula untuk meraih kehidupan di amsa depannya. Individu yang memiliki konsep diri yang positif adalah individu yang memahami betul tentang dirinya sehingga akan menerima kelebihan dan kekurangannya, penilaian tentang dirinya akan semakin positif pandangan hidupnya serta dapat merancang tujuan hidup dalam mengahadapi realita. Dengan demikian, kepala RA Kota Pekanbaru yang memiliki konsep diri yang tinggi maka berpengaruh kuat terhadap motivasi kerjanya dalam memimpin lembaga pendidikan yang berbasis pada aspek-aspek perkembangan anak usia diri. Kematangan seseorang merupakan kesiapan seseorang untuk menampilkan suatu tugas yang dibebankan (Wahyuni, 2004).

Pengaruh yang signifikan dan positif pada konsep diri terhadap motivasi kerja kepala RA mengungkapkan bahwa konsep teori yang pernah diajukan sesuai hasil penelitian yang telah dilakukan oleh peneliti. Hal itu, membuktikan bahwa bagian dari penentu motivasi kerja 
Ida Windi Wahyuni, Alucyana, Dian Tri Utami (Pengaruh Konsep Diri, Masa Kerja)

seseorang dipengaruhi oleh konsep diri. Dengan demikian, hipotesa pertama yang diajukan dalam penelitian ini dinyatakan terbukti.

Hasil analisis statistik antara masa kerja terhadap motivasi kerja kepala RA diperoleh koefisien korelasi $(r)=0,043$ dan koefisien determinasi $\left(r^{2}\right)=0,002$. Hasil penelitian dengan nilai $\mathrm{RS}$ quare sebesar 4\% $(0,043)$, lebih rendah dari nilai $\sigma=5 \%$ dan nilai $\mathrm{F}$ sebesar 6,904 di atas nilai $10 \%$ yang menunjukkan tidak adanya gejala multikolinearitas. Selanjutnya, dapat dinyatakan bahwa masa kerja dapat mempenagruhi motivasi kerja. Penelitian ini menunjukkan hasil yakni salah satu penentu keberhasilan motivasi kerja dipengaruhi oleh masa kerja. Makin lama masa kerja kepala RA Kota Pekanbaru, makin tinggi motivasi kerjanya. Lamanya masa kerja akan berpengaruh terhadap pengalaman kerjanya sehingga motivasi kerjanya pun akan semakin tinggi.

Latar belakang pendidikan memiliki pengaruh terhadap motivasi kerja kepala RA, dinyatakan dalam hasil penelitian dengan nilai RSquare sebesar $6 \%(0,059)$, lebih tinggi dari nilai $\sigma=5 \%$ dan nilai $\mathrm{F}$ sebesar 6,899 di atas nilai $10 \%$ yang menunjukkan tidak adanya gejala multikolinearitas. Penelitian ini menayatakan bahwa latar belakang pendidikan berpengaruh cukup kecil terhadap motivasi kerja kepala RA Kota Pekanbaru.

Selanjutnya, hasil analisis statistik antara konsep diri dan masa kerja terhadap motivasi kerja kepala RA diperoleh koefisien korelasi $(r)=0,279$ dan koefisien determinasi $\left(\mathrm{r}^{2}\right)=0,078$. Hal ini berarti ada pengaruh yang kuat antara konsep diri dan masa kerja terhadap motivasi kerja, dapat disimpulkan bahwa kontribusi konsep diri terhadap motivasi kerja sebesar $1 \%$. Hasil ini memperlihatkan bahwa konsep diri dan masa kerja merupakan salah satu faktor yang berpengaruh terhadap motivasi kerja.

Adapun hasil penelitian antara konsep diri, masa kerja dan latar belakang pendidikan memiliki pengaruh terhadap motivasi kerja kepala RA, dinyatakan dalam hasil penelitian dengan nilai RSquare sebesar $28 \%(0,282)$, lebih tinggi dari nilai $\sigma=5 \%$ dan nilai $\mathrm{F}$ sebesar 6,913 di atas nilai 10\% yang menunjukkan tidak adanya gejala multikolinearitas. Penelitian ini menyatakan bahwa konsep diri, masa kerja dan latar belakang pendidikan berpengaruh cukup tinggi terhadap motivasi kerja kepala RA Kota Pekanbaru. Hasil analisa data pengaruh konsep diri, masa kerja dan latar belakang pendidikan terhadap motivasi kerja menunjukkan nilai signikansi (Sig.) 0,010 dengan nilai $\sigma$ (derajat signifikan) 0,05 , artinya $0,01<0,05$; maknanya adalah terdapat pengaruh yang signifikan antara pengaruh konsep diri, masa kerja dan latar belakang pendidikan terhadap motivasi kerja kepala RA Kota Pekanbaru. 
Semangat serta dorongan baru ditimbulkan oleh motivasi kerja. Penggerak untuk menciptakan semangat kerja dalam bekerjasama, kerja efektif dan selaras dengan usaha untuk meraih kepuasan kerja. Kepala RA dengan motivasi kerja yang tinggi mendorong rohaninya untuk terus berusaha dengan maksimal demi keberlangsungan sekolah yang dipimpinnya dalam mencapai tujuan sekolah maupun tujuan individual, telah dibuktikan dalam penelitian ini yang dinyatakan bahwa motivasi kerja Kepala RA telah dipengaruhi oleh konsep diri, masa kerja dan latar belakang pendidikan.

\section{PENUTUP}

\section{Simpulan}

Adanya pengaruh yang signifikan antara pengaruh konsep diri, masa kerja dan latar belakang pendidikan terhadap motivasi kerja kepala RA Kota Pekanbaru. Disarankan untuk peneliti yang memiliki minat dengan tema yang sama hendaknya memperkaya dengan kajian lain, seperti dukungan sosial, profesionalisme, kinerja dan sebagainya atau menambah jumlah responden lagi dengan memperluas jangkauan lokasi penelitian.

\section{DAFTAR PUSTAKA}

Hasibuan, M. (2017). Manajemen Sumber Daya Manusia. Edisi Revisi. Jakarta: Bumi Aksara.

Iskandar, U. (2013). Kepemimpinan Kepala Sekolah dalam Peningkatan Kinerja Guru. Jurnal Visi Ilmu Pendidikan, 10(1).

Ismail, F. (2018). Manajemen berbasis sekolah: solusi peningkatan kualitas pendidikan. Jurnal Ilmiah Iqra, 2(2), 1-17.

Kunadi, P. P. D. (2013). Pengaruh Motivasi Kerja dan Kompetensi Kepala Sekolah terhadap Keefektifan Kinerja Sekolah Dasar di Kecamatan Sleman. Hanata Widya. Skripsi. Yogyakarta: Universitas Negeri Yogyakarta.

Librianty, N. (2019). Studi Tentang Peran Kepemimpinan Kepala PAUD. Aulad: Journal on Early Childhood, 2(1), 9-17.

Maria, U., \& Nuryoto, S. (2007). Peran Persepsi Keharmonisan Keluarga dan Konsep Diri terhadap Kecenderungan Kenakalan Remaja (Doctoral Dissertation, Universitas Gadjah Mada).

Mashiitahili. (2010). Motivasi Kerja Pegawai. http://mashuritahili.blogspot.com.

Mulyasa, E. (2012). Manajemen dan Kepemimpinan Kepala Sekolah. Jakarta: Bumi Aksara. Munfarijah, S. (2015). Upaya Meningkatkan Motivasi Kerja dan Kreativitas dalam Kepemimpinan PAUD. Jurnal Kependidikan, 3(2), 163-182.

Nurkolis. (2005). Manajemen Berbasis Sekolah. Jakarta: Grasindo 
Rahmania, R., Suntoro, I., \& Kandar, S. (2014). Pengaruh Konsep Diri, Motivasi Berprestasi dan Supervisi Akademik terhadap Kompetensi Paedagogik Guru. Jurnal Manajemen Mutu Pendidikan, 2(2)

Rivai, H. V., \& Arifin, A. (2009). Islamic Leadership: Membangun Super Leadership melalui Kecerdasan Spiritual. Jakarta: Bumi Aksara.

Rosilawati, S. (2005). Hubungan antara Konsep Diri dengan Kinerja Guru MTs Sekecamatan RancaBungur Bogor Skripsi. Jakarta: UIN Syarif Hidayatullah.

Schunk, D. H., Pintrich, P. R., \& Meece, J. L. (2012). Motivasi dalam Pendidikan: Teori, Penelitian, dan Aplikasi. Jakarta: PT. Indeks.

Wahyuni, I. W. (2011). Hubungan Kematangan Beragama dengan Konsep Diri. Al-Hikmah: Jurnal Agama dan Ilmu Pengetahuan, 8(1), 1-8.

Wahyuni, I. W., \& Ancok, D. (2004). Hubungan antara Persepsi Gaya Kepemimpinan Situasional dan Efektivitas Komunikasi Interpersonal dengan Komitmen Kerja (Studi Kasus pada Perawat di Rumah Sakit Siti Khodijah Sepanjang Sidoarjo Jawa Timur). Sosiosains, 17(2004). 